4 Zur Hausen, H, et al, Nature, 1970, 228, 1056.

5 Clements, G B, Klein, G, and Povey, S, International fournal of Cancer, $1975,16,125$.

${ }^{6}$ Wolf, H, Zur Hausen, H, and Becker, V, Nature, New Biology, 1973, 244, 245.

7 Shope, T, Dechairo, D, and Miller, G, Proceedings of the National Academy of Sciences, 1973, 70, 2487.

${ }^{8}$ Falk, L, et al, International fournal of Cancer, 1976, 17, 785.

${ }^{-}$Miller, G, et al, Proceedings of the Society of Experimental Biology and Medicine, 1971, 137, 1459 .

10 Epstein, M, fournal of the National Cancer Institute, 1976, 56, 697.

11 Churchill, A E, Payne, L N, and Chubb, R C, Nature, 1969, 221, 744.

12 Laufs, R, and Steinke, H, Nature, 1975, 253, 71.

${ }^{13}$ Laufs, $\mathrm{R}$, and Steinke, H, Proceedings of the 2nd International Symposium on Oncogenesis and Herpes Viruses, Nuremberg, 1974, part II, eds G de The, M A Epstein and H Zur Hausen, p 345. Lyon, IARC Scientific Publications, No 11, 1975.

14 Kaaden, O R, and Dietzschold, B, Fournal of General Virology, 1974, 25, 1.

15 Pearson, G, Henle, G, and Henle, W, fournal of the National Cancer Institute, 1971, 46, 1243.

${ }^{16}$ Manolov, G, and Manolova, Y, Nature, 1972, 237, 33.

17 Nilsson, K, and Ponten, J, International fournal of Cancer, 1975, 15, 321

18 Ho, J H C, Advances in Cancer Research, 1972, 15, 57.

19 Simons, M J, et al, Proceedings of the 2nd International Symposium on Oncogenesis and Herpes Viruses, Nuremberg, 1974, part II, eds G de Thé, M A Epstein and $H$ Zur Hausen, p 249. Lyon, IARC Scientific Publications, No 11, 1975.

${ }^{20}$ Klein, G, New England fournal of Medicine, 1975, 293, 1353.

21 Glaser, R, and Nonoyama, M L, fournal of Virology, 1974, 14, 174

22 Burkitt, D P, Fournal of the National Cancer Institute, 1969, 42, 19.

\section{Medical migration: go East, young man?}

Despite all the warning cries, the fall of the axe has still been sudden. Last month the Canadian authorities announced ${ }^{1}$ that medical immigration was coming to a virtual end; now the United States Educational Commission for Foreign Medical Graduates has ruled that from 9 January 1977 new regulations ${ }^{2}$ will effectively restrict entry visas for doctors to those who have been invited to the USA either to teach or to do research. This is not the result of a sudden change in the political wind (though isolationism is once more a respectable doctrine). Quite simply, most of the Old Commonwealth countries and the USA are now producing enough of their own medical graduates to staff their medical services. The days when discontented British doctors could find attractive jobs when and where they chose have gone, and probably for ever: young men who did not go West will now have to look to Europe or to the Middle East.

Indeed, by a coincidence of timing, as the shutters have come down in the West they have been opened across the Channel. Public interest in the European Community has been focused on direct elections, the beef and butter mountains, fishing limits, Mr Roy Jenkins, and the green pound, and beside these the success of the scheme for free movements of doctors within the EEC may seem a minor matter. Yet it has been a notable achievement in European harmony and one to which British doctors, and in particular the BMA, have substantially contributed. Last week (11 December, p 1462) and this (p 1515) our Briefing has explained the workings of the Common Market as it concerns doctors. Now that the medical directives are in gear-after 16 years or so of arguments and preparation-the big question is, Will 19 December see the start of a medical merry-go-round in Europe? Or will there be just a handful of doctors wanting to drive across their countries' borders?

For a while, anyway, the language barrier (though under the Treaty of Rome it will not be a legal impediment) may prove to be a practical brake on British doctors heading across the Channel. Certainly there should be no difficulties over professional standards, as our medical schools and postgraduate training can match the best of the Continent. But jobs must also be available before a doctor can contemplate migrating.

Closer to home, these changes provide further evidence of the need for flexibility in our medical manpower planning. For the last ten years or so most expert projections have assumed that 400-500 British trained doctors emigrate each year. That figure may very easily prove to be an overestimate for $1977-80$, but beyond then who knows? By the end of this decade enough pioneers will have tried medical practice in Europe for their experiences to have become common knowledge.

But as Parkhouse has recently argued, ${ }^{3}$ convincingly and in detail, most of the other assumptions which govern planning of medical student numbers are equally subject to external factors over which Britain has little control. The central paradox - still almost unbelievable to any detached outside observer-is that, if our medical schools provide the NHS with just enough doctors to replace retiring and dying GPs and consultants, there are large deficiencies in junior staff. ${ }^{4}$ Put the other way, if all our junior hospital posts are filled with British graduates then many would have a prospect of unemployment by the age of 30 . We have been able to maintain the system only by importing each year 3000 overseas doctors and exporting most of them a few years later. In comparison with this turnover the net annual migration of 450 British graduates is of little short-term importance. Will overseas doctors continue to come now that TRAB is making entry more difficult? Will they continue to leave now that passage across the Atlantic is virtually barred-and, unlike British graduates, they have so far been denied free entry into Europe, despite the BMA's efforts to stop this discrimination?

The third and most important imponderable (long term) is the rate of growth of the NHS. Twenty years on, Parkhouse ${ }^{3}$ suggests, the NHS might have 72000 doctors working for it, in which case he calculates we should need to train 4900 doctors a year. Or, if economic growth is poor and NHS medical staffing is frozen, we might have only 60000 doctors, when the appropriate output would be 2880 doctors a year. Which figure is more realistic?

Like population projections, to some extent manpower projections have to rely on guesswork. No one can be certain of future trends in the birth rate or in the economic prosperity of the country. But we may reasonably ask the DHSS and the Department of Education and Science what their broad policies are. Do we plan to replace foreign doctors in the junior hospital grades by our own graduates? If so, what are the plans for the longer term careers of this "bulge" of new graduates? Do we still intend to expand medical staffing in the NHS at the present rates of $4 \%$ for consultants and $1 \%$ for GPs-or are there plans for revising the balance between doctors and other ancillary workers ? Furthermore, is the NHS still intended to expand now that population growth seems to have ceased ?

Only after these decisions have been taken can we make any rational decisions about medical student numbers. Moreover, only after those decisions have been taken will we be able to decide whether it is rational to set in motion the logical implication of the RAWP plan-which is to close one, or possibly two, London medical schools in order to maintain the standards of the rest.

${ }^{1}$ British Medical fournal, 1976, 2, 1395.

2 Health Professions Educational Assistance Act 1976 (PL 94.484) Title VI.

3 Parkhouse, J, Proceedings of the Royal Society of Medicine, 1976, 69, 815.

4 Parkhouse, J, and McLaughlin, C, Lancet, 1975, 1, 211. 